\title{
10
}

\section{ANALYZING POLISH AND CZECH HARD COAL-MINING TRADE UNIONS AND THEIR POSITIONS TOWARD EU CLIMATE AND ENERGY POLICY}

\section{Tomasz Kubin}

\section{Introduction}

Climate and energy policy has developed into one of the most important common EU policies. In December 2008, general objectives known as the Climate and Energy 20-20-20 Package were approved by the European Council. It is a set of legally binding acts to ensure that the EU achieves three targets by the year 2020: a 20\% reduction of greenhouse gas emissions (from 1990 levels), 20\% energy from renewable sources, and a $20 \%$ improvement in energy efficiency. ${ }^{1}$ At three meetings in 2014, the Council discussed and reaffirmed the EU's efforts to combat climate change and adopted the EU's framework goals by 2030. The goals for renewables and energy efficiency were revised upward in 2018 and now stipulate at least 40\% cuts in greenhouse gas emissions (from 1990 levels), at least a 32\% share of renewable energy (originally $27 \%$ ), and at least a $32.5 \%$ improvement in energy efficiency (originally 27\%). In 2018, the European Commission submitted a proposal for a Multiannual Financial Framework for 2021-2027, proposing a target of $25 \%$ of the entire EU budget for climate goals (European Commission, 2018).

A European Green Deal was one of the first objectives of the new President of the European Commission Ursula von der Leyen (2019), and in December 2019, the European Council endorsed the aim of a climate-neutral EU by 2050. However, as stated in the conclusions, "at this stage, one member state cannot commit to implement this objective as far as it is concerned" (European Council, 2019) and the European Council would come back to this problem in June 2020. The conclusions did not include the country's name, but it was Poland, where hard coal is the largest raw material for electricity production. Moreover, Poland is currently not planning to abandon hard coal burning as the primary source of electricity production. The current shape of the energy sector in Poland (and other CEE countries), including high dependence on hard coal, is largely a heritage of the past (Horváthová and Dobbins, 2019). Poland has the largest 
amount of hard coal by EU comparison, and it has been one of its most important industries for many decades, long before the 1989 transformation. Later, the size of the hard coal-mining (HCM) sector in Poland decreased, but its political and economic significance remains high. Due to the many active coal organizations and their ties with political parties as well as the strong political polarization of society and political calendar, mining trade unions are among important interest groups in Poland, not least because the social movement and the then trade union "Solidarity" was crucial in overthrowing communism.

The Czech Republic is the EU's second-largest hard coal producer. Together with Poland, Hungary, and Estonia, it blocked the adoption of the climate neutrality target for 2050 at the June 2019 Council meeting. However, the level of hard coal extraction is much lower than in Poland, resulting in its lower economic and political significance. Nevertheless, the policies of these strong coal-mining states directly affect the EU's climate and energy goals. Against this background, this chapter explores how the main organized interests and, in particular, trade unions impact their energy policies and, more specifically, how they shape the Polish and Czech governments' positions on the EU's climate and energy policy.

Drawing on the theoretical literature on interest groups, I explore how HCM trade unions justify their position toward EU climate and energy policy. Following up on Mahoney's observations (2007) that the more attention the public pays to a specific decision, the more difficult it should be for special interest groups to influence outcomes, I explore whether mining trade unions have adopted a specific tactic, i.e., either "silencing" the issue (making it easier for them to achieve their goals) or "publicizing" their position and striving to persuade other social groups. I, then, address to what extent the positions and activities of HCM unions have shaped government policy toward EU climate and energy policy. And, finally, I address why the Czech Republic changed its position at the December 2019 European Council meeting. While doing so, I specifically focus on how organized interests produced different outcomes in both countries.

In the upcoming section, I present my theoretical assumptions. The third section is devoted to the empirical analysis, which explores the trade unions' attitudes toward EU climate and energy policy, the arguments they use, while also assessing their influence on both governments' positions. In the final section, I readdress the research questions. As data sources, I rely on official trade union documents and statements by their leaders. Documents from Polish trade unions were obtained directly from representatives of these unions and/or their websites, while the Czech data on HCM unions were generally available on the internet.

\section{Trade unions as organized interest groups - theoretical assumptions}

Interest groups are key actors at the national, regional, and global level (Orach, Schlüter, \& Österblom, 2017) as they enable people to express their opinions to decision-makers (Dür \& De Bièvre, 2007). Taking into account three criteria - 
organization, political interest, and informality (Beyers, Eising, \& Maloney, 2008) - trade unions are among the most prominent interest groups. During the political and economic transformation, the significance of large, formal, membership-based Polish and Czech trade unions has declined, whereas relatively small NGOs have become more important (Ekiert, Kubik, \& Wenzel, 2017). Despite this general assessment, trade unions are still relatively vigorous and influential in some sectors, in particular those under state ownership (e.g., education, health care, railways, energy). Their political significance is primarily due to their resources, the high level of unionization in these sectors, their strong commitment to the political process and links to political parties, and their ability to mobilize resources (including organizing strikes, blocking transport infrastructure, and even using violence).

The restructuring of the Polish and Czech HCM sectors has been going on almost continuously since 1990. This was necessary primarily for economic reasons, whereby the general goal was (and still is) to sustain the profitability of coal-mining. Among other things, this has resulted in a decrease in production, the number of active mines, and employment. The objectives of the EU climate and energy policy are the next big challenge for the HCM sector, especially in Poland, which forced the HCM trade unions to take a position and aim to shape government policy.

The social, economic, and political contexts of interest group activity are one of the key factors shaping their real impact on policy outcomes. Hence, how interest groups convey their arguments may be crucial. As Beyers, Eising \& Maloney (2008, p. 1106) write, "this aspect is often called political advocacy, which refers to all efforts to push public policy in a specific direction on the behalf of constituencies or a general political idea." We can assume that the more an interest group raises arguments going beyond its own particular interests and that can be recognized by other social groups, the greater the chance of influencing policy outcomes. This strategy may be particularly important regarding energy and climate issues, which de facto directly affects all social groups, individuals, and economic sectors. Thus, essentially, every political party aspiring to power takes a stand on energy and climate due to their fundamental importance. Therefore, the right strategy of a given interest group, appropriate instruments for its implementation, and implementation itself are keys to achieving goals.

It is particularly important how significant and present an issue is in the public space in which a given interest group operates. As Christine Mahoney (2007) states, interest group influence may depend on the salience of a given problem, that is, the less notice public opinion pays to a given issue, the greater the chances for the interest group to shape the final policy decision. However, argumentatively "going beyond" its own particular interests, and presenting its activity as defending the interests of other social groups, may also be an effective strategy for interest groups.

In general, though, it is notoriously difficult to measure the influence of organized interests. Yet qualitative comparative analysis (Horváthová \& Dobbins, 
2019) provides a partial solution to this challenge. Following Dür (2008) and taking into account the specifics of the topic of the study and its aims, I, therefore, draw on the preference attainment method. To reconstruct events, it is necessary to identify (1) interest groups and the issues on which they take positions and try to influence policy outcomes, (2) the most important contextual factors, (3) the most important other engaged stakeholders, (4) and the final policy outcome. This helps us to trace the actual impact of interest groups.

In the following, I show that numerous factors were crucial in explaining the divergent developments in both countries. Besides Poland being the largest producer of hard coal and having a large number of workers in this sector, several very important factors explain the advantageous position of HCM trade unions despite the steady decline of the economic importance of coal, i.e., the state's control over the sector, the energy mix based on hard coal combustion, the number, density, and level of organization of mining trade unions, and political involvement and close ties with political parties. Moreover, history is key because "Solidarity" was not only a trade union but, most of all, a social movement opposing the communist authorities. Despite being the second-largest hard coal producer in the EU, the Czech coal-mining sector and trade unions operating in it are much smaller. Its share in energy production is very small, while sector employment is several times lower than in Poland, and general mining production more than 12 times less. There is de facto one trade union in the entire hard coal sector, whose influence on political decisions is relatively low.

\section{Empirical analysis}

Trade unions in Poland are grouped into three confederations: Independent Self-governing Trade Union "Solidarity” (Niezależny Samorzadny Związek Zawodowy "Solidarność"), All-Poland Alliance of Trade Unions (Ogólnopolskie Porozumienie Zwiazków Zawodowych, OPZZ), and Trade Unions Forum (Forum Zwiazków Zawodowych, FZZ). In terms of significance and political influence, the most important are: National Hard Coal Mining Section "Solidarity" (Krajowa Sekcja Górnictwa Węgla Kamiennego "Solidarność"), which is the organizational unit of NSZZ Solidarnos'c, Miners' Trade Union in Poland (Zwiazek Zawodowy Górników w Polsce, $Z Z G w P$ ), belonging to OPZZ, and the Trade Union "Kadra" (Zwiazek Zawodowy "Kadra", ZZ "Kadra”), belonging to FZZ.

In 2017, the level of unionization both in Poland and in the Czech Republic was $12 \%$, which was significantly below the European average (28\% in 2017). Trade union density has dropped in both countries in recent years compared to 2000: in Poland by 4\% and in the Czech Republic by 6.9\% (Vandaele, 2019). In Poland, the trade union system is highly pluralistic, and there are about 25,000 individual trade unions. Three-quarters of all company unions belong to one of the three trade union confederations: NSZZ Solidarnos'ć, OPZZ, or FZZ (Trappmann, 2012) (see below). According to data for 2012, NSZZ Solidarnos'c had around 623,000 members, OPZZ around 793,000 members, and FZZ around 408,000 members. ${ }^{2}$ 
The biggest Czech trade union confederation is the Czech-Moravian Confederation of Trade Unions (Českomoravská konfederace odborových svazü, ¿̌MKOS). In 2015, 29 trade unions with approximately 287,000 members ${ }^{3}$ belonged to ĆMKOS. The most important trade union operating in the HCM sector is the Trade Union of Mining, Geology and Oil Industry Workers (Odborovy Svaz Pracovniki Hornictví, Geologie a Naftového Primyslu, OS PHGN). Within the framework of OS PHGN, there is an Association of Mining Unions (Sdružení hornických odbori, SHO).

\subsection{Polish trade unions' positions toward EU climate and energy policy}

Polish trade unions operating in the HCM sector have long been strongly opposed to many key assumptions of the EU's climate and energy policy. For example, in a 2014 letter to the then Prime Minister Donald Tusk, NSZZ Solidarnośc took the position that EU goals for 2030 to reduce $\mathrm{CO}_{2}$ emissions and increase the share of renewable energy are "from the point of view of the Polish raison d'état absolutely unacceptable" and would mean the loss of several hundred thousand jobs and an increase in energy prices. (NSZZ Solidarnos'́c, 2014). In the same year, in a joint petition to Donald Tusk, mining trade unions called for vetoing the so-called second EU energy and climate package, "taking into account Polish socio-economic conditions and the state's energy security" (Związki Zawodowe, 2014a). This view was repeated in the letter of the mining trade unions to the then Prime Minister Ewa Kopacz (Związki Zawodowe, 2014b). All three major mining trade unions - ZZ Kadra, NSZZ Solidarnos'ć, and ZZG - in Poland called the participants of the February 2018 meeting with the Polish Ministry of Energy "eco-terrorists" (Związki Zawodowe, 2018a).

ZZ Kadra recognizes the threats arising from the functioning of the EU Emissions Trading Scheme in Poland, which in its view may result in the loss of hundreds of thousands of jobs. ZZ Kadra in 2017 expressed support for the general idea of establishing the Just Transition Fund to supplement the European Regional Development Fund and European Social Fund and being financed from the ETS system in the amount of $2 \%$ of revenues (Kadra, 2017).

HCM trade unions in Poland were very active on the occasion of the Katowice COP24 summit in 2018. The international scale of the summit and related events have been evoked by trade unions to convince Polish and foreign public opinion and political decision-makers of their arguments. Cooperation among mining trade unions and a unified position strengthened their message and position in seeking to influence political authorities. Thus, in line with Klüver (2011) and Mahoney (2007), they aimed to build a coalition and raise arguments that could be considered justified by wider social groups.

In the petition of the National Section of Hard Coal Mining NSZZ Solidarnos'c from January 21, 2019, statements by representatives of the Polish authorities regarding COP24 Katowice were "more or less in line with the mainstream current in COP24 - trend toward decarbonization, phasing out of coal, which for our state, and especially for Upper Silesia and the Dąbrowa Basin, means 
economic death and permanent impoverishment of society." The announcement of "a drastic reduction in the share of coal in the Polish energy mix" contained in the Polish Energy Policy until 2040 was also criticized (NSZZ Solidarność, 2019a).

The opposition of the Polish Prime Minister to climate neutrality as a EU goal until 2050, expressed at the June 2019 European Council meeting, was echoed by the Executive Board of the Śląsko-Dąbrowski Region of NSZZ "Solidarnos'ć" with huge approval. According to NSZZ Solidarnos'ć, the acceptance of such a plan would mean "a catastrophe for the Polish economy and permanent impoverishment of the inhabitants of our state." The Prime Minister's position was recognized as "the first example of successful pursuit of the Polish raison d'état in the area of EU climate and energy policy in many years" (NSZZ Solidarnośc 2019b).

In a letter containing comments on the draft Polish energy policy until 2050, ZZ Kadra expressed the view that the objectives of the EU climate policy until 2030 for Poland are "unrealistic" and the energy industry based on Polish hard coal and lignite is "the surest investment in the future and security of the state" (Kadra, 2015). According to ZZ Kadra, Poland's energy policy should be based on hard coal and lignite, followed only by natural gas and renewable energy sources (Kadra, 2017a).

Zwiazek Zawodowy Górników (Miners' Trade Union) in Poland also took a critical stance and negatively assessed the assumed decline in the importance of hard coal as an energy resource. It argued that Poland's own hard coal and lignite resources ensure the country's energy security and that the reduction of hard coal in Poland's energy policy is already part of the European Commission's policy for reducing $\mathrm{CO}_{2}$ emissions. This will result in the need to further restructure the HCM sector, job losses, and thus Poland's loss of energy sovereignty and degradation of the main HCM regions, i.e., Upper Silesia, Małopolska, Lublin (ZZGP, 2015).

\subsection{Czech trade unions' positions toward EU climate and energy policy}

In recent years, the trade union operating in the Czech HCM sector has focused on social problems and paid less attention to the EU energy and climate policy. Following the announcement of insolvency by New World Resources (May 2016), the OKD company was nationalized. The mining trade union strongly supported nationalization and blamed all Czech governments after 1991 for OKD's bankruptcy (Stanovisko Sdružení, 2017). OS PHGN mainly focuses on the annual negotiation of collective agreements and higher-level collective agreements (Kolektivní smlouvy vyěšího stupnè). These documents regulate matters related to working conditions, such as working time, remuneration, work safety, etc. Regarding social issues, two very important events in the HCM industry in which OS PHGN was engaged were the reduction of the retirement age for miners and regulation (Act 167/2016) and mitigating the social effects of restructuring or termination of activities of entities dealing in HCM concerning OKD. 
The OS PHGN trade union program neither for 2012-2016 (OS PHGN, 2012) nor for 2016-2020 (OS PHGN 2016a) contains any specific provisions regarding the EU energy and climate policy. Much more important was the content of the call to the Czech Government, which was adopted at the VIII Congress of the OS PHGN in March 2016. According to participants, the state's energy security can only be ensured thanks to its own natural resources, and the greater the independence on imported raw materials, the higher the level of security of the Czech Republic. Trade unionists of OS PHGN called on the Czech government not to succumb to the "mindless" pressure of "ecological fanatics" at the national, European, and global level (OS PHGN, 2016b).

To sum up, the attitude toward the goals of the EU energy and climate policy of all major Polish and Czech HCM trade unions is essentially the same. This also applies to OS PHGN, the de facto only Czech HCM trade union. However, it should be emphasized that while Polish mining unions devoted much attention to the EU energy and climate policy, OS PHGN focused on the survival of OKD after the bankruptcy of New World Resources and the (effective) fight for social rights. The position on the EU energy and climate policy was expressed by trade union activists (see Table 10.1).

\subsection{HCM trade union arguments justifying their stances}

Based on official documents and interviews with Czech trade union activists ${ }^{4}$ on the internet, Polish and Czech HCM trade unions put forward arguments, which can be categorized as follows (Table 10.1).

It is apparent that the arguments of Polish and Czech mining trade unions coincide and their rhetorical tactic is the same, i.e., although interest groups like trade unions "exclude[...] broad movements and waves of public opinion that may influence policy outcomes" (Beyers, Eising, \& Maloney, 2008, p. 1106), mining trade unions refer to arguments that go beyond their particular interests

TABLE 10.1 Arguments in opposition to EU climate and energy policy

\begin{tabular}{ll}
$\begin{array}{l}\text { Type of } \\
\text { argument }\end{array}$ & Explication \\
\hline $\begin{array}{l}\text { Related to climate } \\
\text { change }\end{array}$ & "the opinions of scientists regarding the impact of man \\
& on climate change and the effects of these changes are \\
& differentiated" (NSZZ Solidarnośc, 2019b). \\
- & "global warming theses are based on a scientific theory that \\
has not yet been reliably proven" (Sábel, 2017). & "CO 2 can be absorbed by forests" and coal can be used in a \\
& way "that does not involve negative environmental impacts", \\
& (Spoleczny Pre_COP24).
\end{tabular}




\begin{tabular}{|c|c|}
\hline $\begin{array}{l}\text { Type of } \\
\text { argument }\end{array}$ & Expli \\
\hline $\begin{array}{l}\text { Related to the } \\
\text { desirability of } \\
\text { EU climate and } \\
\text { energy policy }\end{array}$ & $\begin{array}{l}\text { - "the EU has a small share of global } \mathrm{CO}_{2} \text { emissions and thus a } \\
\text { small impact on the Earth's climate" (Sábel, 2019b). } \\
\text { - "costs of climate policy should be borne primarily by } \\
\text { consumers of goods and services containing a carbon footprint } \\
\text { from richer countries, and not their producers from poorer } \\
\text { countries" (Związki zawodowe, 2018b); } \\
\text { - "EU policy is the result of lobbying corporations operating in } \\
\text { the renewable energy sector" (Sábel, 2019a). } \\
\text { - "coal burning by utility power engineering does not } \\
\text { contribute to the formation of smog in the least" and } \mathrm{CO}_{2} \text { "is } \\
\text { not a toxic gas and it has absolutely nothing to do with smog" } \\
\text { (NSZZ Solidarność 2019b). }\end{array}$ \\
\hline $\begin{array}{l}\text { State's energy } \\
\text { security/ } \\
\text { independence }\end{array}$ & $\begin{array}{l}\text { - "EU's climate and energy policy will lead to the EU } \\
\text { becoming dependent on imports of natural gas and coal from } \\
\text { other states" (Sábel, 2019a). } \\
\text { - "solar and wind power plants are unreliable" (Sábel, 2017). } \\
\text { - "considering that Czech nuclear power plants are aging, } \\
\text { the need to import natural gas, the instability of energy } \\
\text { production from renewable sources to ensure energy security } \\
\text { and affordable energy prices for individual consumers and } \\
\text { industry, coal will be irreplaceable" (Franta, 2019). } \\
\text { - "Poland should ensure energy security based its raw materials" } \\
\text { (Społeczny Pre_COP24). } \\
\text { - "COP24 member states should be free to shape their energy } \\
\text { mix" (Społeczny Pre_COP24). }\end{array}$ \\
\hline Social & $\begin{array}{l}\text { - "liquidating hundreds of thousands of jobs" (NSZZ } \\
\text { Solidarnośc, 2019b). } \\
\text { - "permanent impoverishment of society" (NSZZ Solidarność, } \\
\text { 2019b). } \\
\text { - "worsening of the labor market and social security situation" } \\
\text { (Kadra, 2015). } \\
\text { - decarbonization is a "huge threat" for Poland and the future } \\
\text { of Polish families (NSZZ, Solidarnośc, 2019b). } \\
\text { - "increase in energy prices for households" (Kadra, 2017; } \\
\text { Pytlík, 2016); } \\
\text { - "climate policy and environmental protection must not lead to } \\
\text { energy poverty" (Kadra, 2014). }\end{array}$ \\
\hline Financial & $\begin{array}{l}\text { - "very high financial cost - for Poland at least EUR } 200 \\
\text { billion" (NSZZ Solidarność, 2019b). } \\
\text { - "stunting economic development" (NSZZ Solidarność, 2019b). } \\
\text { - "electricity produced from solar and wind power is very } \\
\text { expensive" (Sábel, 2017). } \\
\text { - "higher energy prices" (Związki zawodowe, 2018a). }\end{array}$ \\
\hline
\end{tabular}




\begin{tabular}{|c|c|}
\hline $\begin{array}{l}\text { Type of } \\
\text { argument }\end{array}$ & Explication \\
\hline $\begin{array}{l}\text { Related to the } \\
\text { nature of the } \\
\text { debate on } \\
\text { climate change } \\
\text { and EU energy } \\
\text { and climate } \\
\text { policy }\end{array}$ & $\begin{array}{l}\text { - "the discussion on climate change is dominated by } \\
\text { propaganda and manipulation" (NSZZ Solidarność, 2019b). } \\
\text { - "the public debate is dominated by IPCC reports, treated as } \\
\text { revealed truth, not subject to any discussion or verification } \\
\text { although IPCC forecasts are not later confirmed by reality" } \\
\text { (NSZZ Solidarność, 2019b). } \\
\text { - "the EU seems to be ruled by ecological and climatological } \\
\text { fanatics" (Sábel, 2019b). } \\
\text { - "just transition is only an empty slogan" (NSZZ Solidarnos'c, } \\
\text { 2019b). } \\
\text { - "avoiding discrimination against states whose economies } \\
\text { are particularly dependent on fossil fuels" (Społeczny } \\
\text { Pre_COP24). }\end{array}$ \\
\hline
\end{tabular}

and embrace the general public. In other words, they aim to extrapolate their positions to other social groups, which are not directly or only indirectly connected with the sector.

\subsection{Assessing the impact of trade unions on the Polish and Czech governments' positions toward EU climate and energy policy}

As stated in the theoretical part, the conditions in which interest groups operate and try to influence political decisions are of key importance for assessing their impact. "Interest groups do not develop or operate in a vacuum" (Thomas, 2004, p. 67), and their influence is "highly conditional" (Orach, Schlüter, \& Österblom, 2017, p. 91). The first group of factors concerns the size and employment of the hard coal-mining sector for the Polish and Czech energy balance. The basic data for the period 1990-2018 are included in Table 10.2. It should be noted that currently about $83 \%$ of all hard coal produced in the EU is mined in Poland. However, the Czech share is only about 6\%. What is striking, though, is the very large drop in production, employment and the number of active mines compared to the beginning of the system transformation, both in Poland and in the Czech Republic.

Other key factors affecting Poland's energy and climate policy are its high dependency on coal for electricity production - mainly hard coal (47\% in 2018) and brown coal (29\% in 2018). As reflected in Table 10.3, this is well above the EU average, and the share of electricity produced from hard coal in Poland is by far the highest in the EU. The Czech situation is completely different - it produces only $5 \%$ of electricity from hard coal, while lignite $(43 \%)$ is much more important. The importance of hard coal is greater in the heating sector - in 2014, 
TABLE 10.2 Hard coal in Poland, the Czech Republic and the EU - selected data

\begin{tabular}{|c|c|c|c|c|}
\hline & Year & Poland & $\begin{array}{l}\text { Czech } \\
\text { Republic }\end{array}$ & $E U$ \\
\hline \multirow[t]{5}{*}{ Production $(\mathrm{Mt})$} & 2018 & 63.4 & 4.5 & 76 \\
\hline & 2013 & 76.5 & 8.6 & 114 \\
\hline & 2008 & 83.4 & 12.6 & n.a. \\
\hline & 2004 & 99.2 & 13.3 & n.a. \\
\hline & 1990 & 147.4 & 23.2 & n.a. \\
\hline \multirow[t]{3}{*}{ Imports (Mt) } & 2018 & 19.7 & 3.3 & 166 \\
\hline & 2013 & 10.8 & 2.1 & 216 \\
\hline & 2008 & 9.4 & 2.1 & n.a. \\
\hline \multirow[t]{3}{*}{ Employment (thousand) } & 2018 & 82.7 & 9.5 & n.a. \\
\hline & 2004 & 127.1 & 19.6 & 332.9 \\
\hline & 1990 & 387.9 & 71.7 & n.a. \\
\hline \multirow[t]{3}{*}{ Number of active hard coal mines/units } & 2018 & 21 & 3 & n.a. \\
\hline & 2004 & 39 & 5 & n.a. \\
\hline & 1990 & 70 & 27 & n.a. \\
\hline
\end{tabular}

Source: https://euracoal.eu/info/euracoal-eu-statistics/ (21 December 2019), Euracoal (2005), Euracoal (2013), Euracoal (2018), Alves Dias et al. (2018), World Energy Council (2000), Kaczorowski \& Gajewski (2008).

it generated 17\% of heat (Rečková, Rečka, \& Ščasný, 2017). Secondly, the Czech Republic is a significant net exporter of electricity, while Poland consumes more electricity than it can produce and the shortages must be covered by import.

The document Poland's energy policy until 2040 stipulates that in 2030 about $56 \%-60 \%$ of electricity will be produced from coal in Poland. This means a slow phasing out of coal as a raw material (in 2018 it was 76\%, Table 10.2) due to the lack of a real alternative in the short and medium term.

Another significant impediment to a more progressive energy policy is that the government - which HCM unions try to influence - is simultaneously the actual owner of almost all mines in Poland (directly or indirectly through subsidiaries). ${ }^{5}$ The same applies in the Czech Republic, since the only producer, OKD, until 2017 owned by New World Resources NV, was nationalized again. Hence, the Polish and Czech governments play multiple roles simultaneously: they are regulators at the national level, policy-makers at the EU level, and owners. Decisions regarding the state's position in the EU are, therefore, taken by mine owners whose future depends on these decisions. Moreover, the Polish government controls all large energy companies, which are the main recipients of coal from state-owned mines. This causes a conflict of interest - on the one hand, the state as the entity controlling the energy sector is concerned about the cheapest coal supplies (even from imports), on the other hand, it is against the interests of mines, which are also state-owned. As a result, energy companies - whose boards are staffed by political operatives - try to balance between economic rationality and concern for the financial results of enterprises and expectations of 


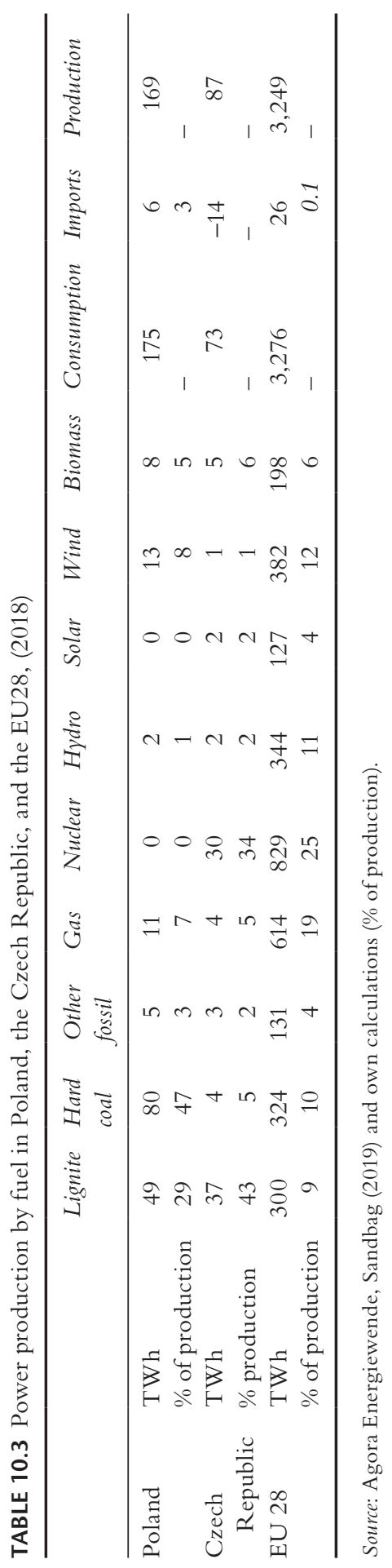


political authorities, that are under pressure from the hard coal sector and which primarily have political goals in mind.

It should also be noted that, currently, about 80,000 people work directly in the Polish HCM sector and about 400,000 jobs in enterprises are linked to mining (according to the Polish Mining Chamber of Industry and Commerce). ${ }^{6}$ A phasing out of coal, therefore, would be a very serious challenge not only for miners but also for many people in other enterprises. This again justifies the tactics of extrapolating to other social groups than just those employed directly in mining.

Altogether, especially in Poland, mining trade unions have greater resources (financial, human) and are able to mobilize larger and more politically significant social groups than ecological organizations and interest groups working for the renewable energy sector. The livelihood of several hundred thousands of families is directly and indirectly connected with the mining sector. Hence they constitute a very significant group of voters, who are particularly important in strongly polarized Polish society. It is additionally worth noting that both countries' green parties play virtually no political role. This is a distinct difference to western European countries, and to some extent, this reflects the dominant social views on issues regarding energy sources and environmental protection.

\subsection{Contrasting the Polish and Czech governments' positions on the EU climate and energy policy}

How do we explain the Czech government's turnaround and ultimate acceptance of the EU's policy of climate neutrality until 2050? In December 2019, before the European Council meeting, Prime Minister Andrej Babiš pointed out that without the activities of other states, EU activity regarding $\mathrm{CO}_{2}$ reduction would be ineffective, that this would mean very high costs for the Czech Republic and would not be possible without EU financial assistance. He stressed that reducing greenhouse gas emissions must not threaten the competitiveness of EU economies. Representatives of the Czech authorities declared that by 2050 they want to increase electricity production in nuclear power plants and from renewable sources. ${ }^{7}$ And according to Popp, trade unions in Czech Republic representing coal miners "have a strong influence on climate and energy policy and are strongly opposed to any measure that might impact coal. They have close ties to the government" (Popp, 2019, p. 5).

There seem to be several fundamental reasons for the Czech Republic's retreat from its initial stance. First, its energy mix contrasts with Poland's, as reflected in Table 10.3. The need to import electricity significantly hinders the transition from hard coal in Poland - simply, in the absence of sources of electricity production other than coal (hard coal and lignite), there is no short- and mediumterm substitute for this raw material. Theoretically, the Czech Republic could completely give up electricity generation from hard coal without significantly reducing its energy security. However, in Poland, the situation is different. On the demand side, what will cause its growth is economic development (the estimated 
increase in electricity demand for this reason is approx. $2 \%-3 \%$ per year), urbanization of large- and medium-sized cities resulting in an increase in demand for system heating (approx. 3\%-4\% per year) and the possible development of electromobility. On the supply side, the oldest power units that cannot be modernized will be phased out.

Even assuming the dynamic development of renewable energy sources and taking into account the current state of affairs and financial capabilities, it is not possible for Poland to soon abandon coal as an energy source. Furthermore, in recent years (2017-2019), a few new coal units have been built or are still under construction: 1,075 MW unit at Kozienice power plant, two 905 MW units at Opole power plant, $910 \mathrm{MW}$ unit at Jaworzno III power plant, $496 \mathrm{MW}$ unit at Turów power plant, and 1,000 MW in Ostrołęka C power plant. ${ }^{8}$

Against this background, Polish mining trade unions not only strongly defend the extraction of coal, but also oppose measures that could impact its future importance for energy production. In 2016, NSZZ Solidarnośc took a very clear position regarding the Polish energy mix: "there never was, there is not, and there can never be approval on our part regarding the construction of a nuclear power plant." This position is justified by the risk of failure and its consequences and the lack of social acceptance (NSZZ Solidarność, 2016).

Summarizing, the position of the Polish government toward the EU energy and climate policy is the result of both the political significance, mobilization, activity and cooperation as well as a unified position on this matter of mining trade unions, and favorable objective conditions. The most important is the Polish energy mix, as fundamental change and phasing out coal would take many years and require significant investments. The Czech situation is different. In accordance with the energy policy of the government, "the aim of the Czech Republic in the area of energy and climate protection is to ensure the transition to a competitive low-carbon economy and to reduce the dependence on fossil fuels" (The Office of the Government of the Czech Republic, 2015, p. 39). In 2020, the share of hard coal in total final energy consumption was to be only $2.7 \%$, and in $2040,2.3 \%$. In total gross electricity production, the share of hard coal in 2020 is $4.6 \%$, and in 2040 , it should be $2.2 \%$. The share of hard coal in the heat supply in 2020 is $15.3 \%$, and in 2040, it should decrease to 10\% (Ministerstvo Prumyslu a Obchodu, 2014). Thus, even though the Czech Republic has typically taken a skeptical stance on low-carbon development, it has often cooperated with the Visegrád Group countries in blocking European climate ambitions. However, it is somewhat more progressive than Poland regarding the EU Emissions Trading System (ETS) and energy efficiency (Popp, 2019, p. 4).

An additional reason is trade union politicization. Informality is a characteristic feature in the sense that interest groups do not normally seek public office or compete in elections, but pursue their goals through frequent informal interactions with politicians and bureaucrats (Beyers, Eising, \& Maloney, 2008). "However, many nonpolitical interest groups are forced to become politically active because there is no other way to protect or promote the interests of their members or an 
organization such as a business" (Thomas, 2004, p. 8). Consequently, the Polish trade union movement is strongly politicized. This situation dates back to 1989 and even earlier, when, in the 1980s, NSZZ Solidarnos'ć was not only a trade union but also a social movement opposing the communist authorities. In the 1990s, trade unions saw and treated political parties and parliamentary representation as a tool of political influence. Several Polish political parties have emerged from the trade union movement, and trade union activists frequently enter politics (Zientara, 2009). Roughly speaking, NSZZ Solidarnos'ć ideologically is center-right and/or right-wing and officially supported the conservative Law and Justice party (Prawo $i$ Sprawiedliwość) in parliamentary elections and their candidates in presidential elections. Since 2015, NSZZ Solidarnośc has become an even stronger ally of Law and Justice. OPZZ is ideologically on the left or center-left and is politically closer to left-wing parties (Democratic Left Alliance, Left Together, Labor Union). FZZ is generally centrist. The most important opposition political party in Poland - Civic Platform - is not linked with any trade union.

These circumstances have very strong practical significance. At a time when the Polish government had to make a decision regarding its position on the EU's climate and energy policy, Poland was de facto in a permanent election campaign. In 2018, local elections were held; in 2019, elections to the European Parliament (spring) and the national parliament (autumn); and in 2020, presidential elections. Under the conditions of very strong rivalry and political polarization in Poland, the Law and Justice government could not risk losing the support of mining trade unions.

In the Czech case, only 9,500 people work in mines (of which approx. 20\% are Poles), which significantly weakens the strength of their political impact. The potential reduction in employment or even the closure of all mines will not have such negative social and political effects as in Poland. Czech trade unions had much less influence on politics after 1989 than Polish trade unions (especially "Solidarity"), and the links between Czech trade unions and political parties are much weaker. "Formally and institutionally independent of any political parties, CMKOS's position is closest to the Czech Social Democratic Party" (Drahokoupil \& Kahancová, 2017, p. 9). It is one of the most important Czech political parties after 1989, and since 2018, it has again joined the government led by Andrej Babiš, but in the 2017 elections, it received only $7.27 \%$ of the vote.

In addition, past experiences are very important. In Poland, the restructuring of the hard coal-mining sector was very turbulent and accompanied by numerous conflicts between the government as the owner of the mines, on the one hand, and miners and trade unions on the other hand, including the use of force during demonstrations by both parties, i.e., by trade unions and the police. In the Czech Republic, in turn, coal-mining restructuring was relatively calm: “in the Ostrava region, the miners' union cooperated with the government - and the government consulted with the union - which led to a peaceful process of restructuring despite the significant decline in employment" (Bruha, Ionascu, \& Jeong, 2005, p. 4). 
The third reason relates to differences in the Polish and Czech trade union systems. One of the most important features of the Polish trade union movement is its fragmentation. The hard coal-mining sector is among the economic sectors with the highest level of unionization, in which several dozen trade unions are active. Very characteristic of the trade union movement in Poland is that it is already very pluralistic. This means not only that there are very many trade unions, but also that in many enterprises, there are several or even several dozen trade unions acting simultaneously. This is most evident in sectors where enterprises are primarily state-owned such as HCM. According to the latest available data, in 2014 in Poland, 72\% of the total employees in the "mining and quarrying" sector belonged to trade unions, which was the highest union density ratio by sector (GUS, 2015). ${ }^{9}$

The very high level of unionization, exceeding several times the national average, with several dozen trade unions operating in one mine, and employees belonging to more than one union causes constant competition and rivalry between trade unions. Thus, in practice, trade unions sometimes try to outbid one another when raising claims (e.g., wage increases, defense of endangered jobs, protests against mines liquidation, conditions of mining restructuring, conditions of employment, opposition to hard coal import, opposition to mine privatization plans, pressure for financial public support). Besides political involvement, trade unions in Poland recently frequently initiated collective disputes and organized various types of protests, demonstrations, petitions, demands, etc.

Another very significant difference in the Czech Republic is the predominance of a one-workplace-one-union principle, a legacy of decentralization after 1990 that eliminates such motivations in trade union activities as in Poland (Veverkova \& Wegenschimmel, 2016). The most prevalent level of collective bargaining is the company level. It is worth adding that, as Mansfeldová writes, strikes are relatively very rare. Trade unions rather tend to declare a strike alert, which is announced during collective bargaining (Mansfeldová, 2015). In Poland, after Law and Justice came to power in 2015 supported by "Solidarity", there were no strikes or very radical forms of protests (during the rule of the Civic Platform in 2007-2015, there was even physical violence used by miners and the police). However, mining trade unions almost always organized forms of protests such as petitions, mass crew demonstrations, underground protests, roadblocks, railway blocks, crew occupation of the mines' offices, strike alerts, or strike referendums.

Therefore, taking into account the energy mix and the much smaller economic importance of HCM and the much smaller political importance of mining trade unions than in Poland, the Czech government changed its position of June 2019 and jointly declared the objective of climate neutrality with other EU countries - except for Poland. Two other very important factors are, first, a very large reduction in coal and lignite stipulated in the Czech Energy Policy until 2040 (Ministerstvo Průmyslu a Obchodu, 2014). Second, moving away from coal will enable the use of the financial resources from the Just 
Transformation Fund, the EU financial instrument supporting regions most affected by the transition toward climate neutrality. Hence, the Czech government considered that the political costs of opposing climate neutrality in the EU arena would be too high.

\section{Conclusions}

The position of Polish and Czech HCM trade unions toward EU climate and energy policy is clearly negative. To justify their opposition, they refer to arguments that go beyond sectoral interests and aim to convey the impression that they also act in the interest of other social groups. Thus, they seek to 'publicize' their position rather than 'silencing' the issue and achieving their goals 'quietly'.

Despite the success of coal-mining organizations in fueling Poland's opposition to phasing out coal, the long-term prospects of this strategy are uncertain. Rising prices of energy produced from coal (a consequence of geological conditions and the EU regulations), together with falling prices of renewable energy, may decrease the importance of coal as an energy resource. This process has been going on in Poland (and Europe) for several decades, and the pressure of mining trade unions may slow it down, but it is not able to stop it.

Altogether, several factors explain the differential clout of mining trade unions on governmental policy. In Poland, there are many more member-strong unions; they have relatively large resources at their disposal; and, importantly, they compete strongly with each other, which promotes the radicalization of their demands and tools used to achieve objectives (strikes or even violence). The political calendar and elections (to local governments, the European Parliament, national parliament, presidential elections), which were held in Poland in 2018-2020, were also very important. For example, in the 2020 Polish presidential election, the difference in the second round between Andrzej Duda - openly supported by the trade union "Solidarity" - and the opposition candidate Rafał Trzaskowski was only about 422,000 , which is almost exactly the number of people estimated employed in mining and sectors directly related to it. Taking into account the energy mix, the Czech Republic may consider it easier to give up energy produced from hard coal, and the social and political effects would be much smaller.

Finally, one cannot neglect the current impact of coronavirus on the sector. High infection rates among coal-miners have turned the traditional mining regions into national epicenters of the pandemic. Resulting short- and long-term health issues may not only weaken the practical organizational capacity of mining unions but also shed further doubt on the sector's viability in the future. This unexpected calamity may further facilitate the decline of the sector not only in the Czech Republic but also in Poland despite the many factors outlined above that have stalled its downsizing. 


\section{Notes}

1 Detailed solutions were included in secondary legal acts: Directive 2009/28/EC, Decision 406/2009/EC and Directive 2009/29/EC.

2 https://www.eurofound.europa.eu/pl/country/poland\#actors-and-institutions (26 December 2019).

3 As Vevekova and Wegenschimmel (2016) note, according to ČMKOS, which does not keep ex-act records on the number of members. Myant (2010, p. 891) writes that

the figure cannot be calculated with precision partly because of uncertainty over the exact level of union membership [...] and partly because unions generally retained pensioners as members and these were often not counted separately. The number of pensioners varied enormously between unions, but often exceeded $20 \%$ of total membership.

4 Jan Sábel - president OS PHGN, Jaromír Franta - president SCO/CCG (Sdružení odborových organizací/Czech Coal Group) Jaromír Pytlík - president SHO OKD (Sdružení hornických odbori̊, Association of Mining Unions in OKD).

5 Only three very small hard coal mines in Poland are 100\% private property: Przedsiębiorstwo Górnicze Silesia Sp. z o.o., Zakład Górniczy Siltech Sp. z o.o. and EkoPlus Sp. z o.o.

6 https://www.slaskibiznes.pl/wiadomosci, firmy-okologornicze-blagaja-o-pomocczy-plan-sasina-to-fikcja, wia5-1-3235.html (22 July 2020).

http://www.solidarnosckatowice.pl/pl-PL/przemysl_okologorniczy_potrzebuje_ wsparcia.html (22 July 2020).

7 Boj s klimatickou změnou bude Česko stát biliony korun, zapojit se ale musí celý svět, 02 December 2019.

https://www.osphgn.cz/clanky/aktuality/boj-s-klimatickou-zmenou-bude-ceskostat-biliony-korun--zapojit-se-ale-musi-cely-svet.html (21 December 2019).

8 In February 2020, owners of the Ostrołęka power plant decided to suspend construction of the $\mathrm{C}$ unit.

9 In the biggest hard coal-mining company in Poland (and EU) - Polish Mining Group (Polska Grupa Górnicza, PGG) around 43,000 people were employed at the end of 2017. In entities of the PGG Capital Group in 2017, there were 148 trade union organizations grouped in 24 trade unions, which included over 40,000 employees, meaning a unionization level of $93.1 \%$. In numbers, the largest trade unions at PGG are: NSZZ Solidarnos'c (24.5\% of the total trade unions members in PGG), ZZG (15.4\%), Sierpień 80" (14.8\%), and Kadra (9.9\%), Związek Zawodowy Ratowników Górniczych (5.4\%), Zwiazek Zawodowy Pracowników Dołowych (5.3\%), other trade unions - 17.8\% (PGG, 2017). In the second biggest mining company in Poland in terms of employment and hard coal extraction - Jastrzębie Coal Company (Jastrzębska Spółka Węglowa, JSW) $-28,268$ people were employed at the end of 2018. At JSW, 125 trade union organizations operated, with 31,739 members. The number of trade union members is higher than the number of JSW employees because each employee may belong to more than one trade union. This meant that the union density rate at JSW was $119.9 \%$ (JSW, 2018). In 2018, the hard coal-mining company in the Lublin Basin - Lublin Coal "Bogdanka” Capital Group (Lubelski Węgiel Bogdanka, LW "Bogdanka”) employed 5,420 people, and six trade unions operated in it, with 3,319 members, which meant that the union density ratio was 70\% (LW Bogdanka, 2018).

\section{References}

Act 167/2016, Nařizení vlády ze dne 11. května 2016 o přispěvku ke zmírnèní sociálních dopadu souvisejicich s restrukturalizací a útlumem činnosti právnických osob $v$ insolvenci zabývajicich se téžbou černého uhlí. Sbirka zákoni̊ č. 167/2016 Sb. 
Agora Energiewende \& Sandbag. (2020). The European power sector in 2018. https:// www.agora-energiewende.de/en/publications/the-european-power-sector-in-2018/ (Accessed 15 July 2020).

Alves Dias, P. et al. (2018). EU coal regions: Opportunities and challenges ahead. Luxembourg. doi: 10.2760/064809

Beyers, J., Eising, R., \& Maloney, W. (2008). Conclusion: Embedding interest group research. West European Politics, 31(6). doi: 10.1080/01402380802372696

Bruha, J., Ionascu, D. \& Jeong, B. (2005). Organized labor and restructuring: Coal mines in the Czech Republic and Romania. William Davidson Institute Working Paper Number 773. doi: $10.2139 /$ ssrn. 729365

Decision No 406/2009/EC of the European Parliament and of the Council of 23 April 2009 on the effort of Member States to reduce their greenhouse gas emissions to meet the Community's greenhouse gas emission reduction commitments up to 2020, Official Journal of the European Union, L 140.

Directive 2009/28/EC of the European Parliament and of the Council of 23 April 2009 on the promotion of the use of energy from renewable sources and amending and subsequently repealing Directives 2001/77/EC and 2003/30/EC, Official Journal of the European Union, L 140.

Drahokoupil, J. \& Kahancová, M. (2017). Workers' participation in Czechia and Slovakia. CELSI Discussion Paper, (44), 1-27. https://www.celsi.sk/media/discussion_ papers/DP44.pdf

Dür, A. (2008). Measuring interest group influence in the EU. European Union Politics, 9(4), 559-576. doi: 10.1177/1465116508095151

Dür, A. \& de Bièvre, D. (2007). The question of interest group influence. Journal of Public Policy, 27(1), 1-12. doi: 10.1017/s0143814x07000591

Ekiert, G., Kubik, J., \& Wenzel, M. (2017). Civil society and three dimensions of inequality in post-1989 Poland. Comparative Politics, 49(3), 331-350. doi: 10.5129/001041517820934230

Euracoal. (2005). Coal industry across Europe 2005.

Euracoal. (2013). Annual report 2013.

Euracoal. (2018). Annual report 2018.

European Commission. (2018). Communication from the commission. A modern budget for union that protects, empowers and defends. Multiannual financial framework 2021-2027, $\operatorname{COM}(2018) 321$ final, Brussels.

European Council. (2019). 12 December 2019. Conclusions, EUCO 29/19.

Franta, J. (2019). Franta: Česko ani Evropa planetu nezachrání. https://www.osphgn. cz/clanky/aktuality/franta--cesko-ani-evropa-planetu-nezachrani.html (Accessed 21 December 2020).

GUS. (2015). Główny Urząd Statystyczny: Związki zawodowe w Polsce w 2014 r. Notatka informacyjna, Warszawa, https://stat.gov.pl/obszary-tematyczne/gospodarka-spolecznawolontariat/gospodarka-spoleczna-trzeci-sektor/zwiazki-zawodowe-w-polsce-w2014-r-, 10,1.html (Accessed 21 December 2020).

Horváthová, B. \& Dobbins, M. (2019). Organised interests in the energy sector: A comparative study of the influence of interest groups in Czechia and Hungary. Politics and Governance, 7(1), 139-151. doi: 10.17645/pag.v7i1.1784

JSW. (2018). Sprawozdanie Zarzadu z działalności Jastrzębskiej Spótki Węglowej S.A. oraz Grupy Kapitałowej Jastrzębskiej Spółki Węglowej S.A. za rok obrotowy zakończony.

Kaczorowski, P. \& Gajewski, P. (2008). Górnictwo węgla kamiennego w Polsce w okresie transformacji. Acta Universitatis Lodziensis. Folia Oeconomica, 219. 
Kadra. (2015). Porozumienie Związków Zawodowych "Kadra”, 340/2015/PZZ/DT, Katowice, 15 September 2015.

Kadra. (2017a). Porozumienie Związków Zawodowych "Kadra”, 187/2017/PZZ/DT, Katowice, 31 October 2017.

Kadra. (2017b). Porozumienie Związków Zawodowych "Kadra”, 23/2017/PZZ/DT, Katowice, 14 February 2017.

Klüver, H. (2011). The contextual nature of lobbying: Explaining lobbying success in the European Union. European Union Politics, 12(4), 483-506. doi: 10.1177/ 1465116511413163

LW Bogdanka. (2018). Sprawozdanie Zarzadu z działalności LW Bogdanka S.A. oraz Grupy Kapitałowej LW Bogdanka za 2018.

Mahoney, C. (2007). Lobbying success in the United States and the European Union. Journal of Public Policy, 27(1), 35-56. doi: 10.1017/s0143814x07000608

Mansfeldová, Z. (2015). Between a rock and a hard place: Czech Trade Unions in domestic and European Arenas. In Ch. Landgraf, H. Pleines (Eds.), Interest representation and Europeanization of trade unions from EU member states of the eastern enlargement (pp. 181-199). Stuttgart: ibidem-Verlag.

Ministerstvo Prümyslu a Obchodu. (2014). State energy policy of the Czech Republic. Prague.

Myant, M. (2010). Trade union influence in the Czech Republic since 1989. Czech Sociological Review, 46(6), 889-912. doi: 10.13060/00380288.2010.46.6.02

NSZZ Solidarnośc. (2014). NSZZ “Solidarność”, Region Śląsko-Dąbrowski, Sekretariat Górnictwa i Energetyki, Katowice, 17 March 2014.

NSZZ Solidarność. (2016). NSZZ “Solidarność”, Sekcja Krajowa Górnictwa Węgla Kamiennego, Katowice, 07 September 2016.

NSZZ Solidarność. (2019a). Krajowa Sekcja GWK NSZZ “Solidarność”, Petycja z 21 January 2019.

NSZZ Solidarnośc. (2019b). Stanowisko Zarzadu Regionu Ślasko-Dąbrowskiego NSZZ Solidarność z dnia 25 czerwca 2019 r. w sprawie odrzucenia przez rzad RP kolejnego zaostrzenia polityki klimatyczno-energetycznej Unii Europejskiej.

Orach, K., Schlüter, M., \& Österblom, H. (2017). Tracing a pathway to success: How competing interest groups influenced the $2013 \mathrm{EU}$ common fisheries policy reform. Environmental Science \& Policy, 76, 90-102. doi: 10.1016/j.envsci.2017.06.010

OS PHGN. (2012). Program OS PHGN na léta 2012-2016. https://www.osphgn.cz/ clanky/dokumenty/ (Accessed 15 April 2020)

OS PHGN. (2016a). Program OS PHGN na léta 2016-2020. https://www.osphgn.cz/ clanky/dokumenty/ (Accessed 15 April 2020)

OS PHGN. (2016b). Výzva delegátů VIII sjezdu Odborového svazu pracovníků hornictví, geologie a naftového prümyslu. https://www.osphgn.cz/clanky/dokumenty/ (Accessed 15 April 2020).

PGG. (2017). Sprawozdanie na temat informacji niefinansowych Grupy Kapitałowej Polskiej Grupy Górniczej S.A za 2017 rok.

Popp, R. (2019). A just transition of European coal regions. Assessing stakeholder positions towards the transition away from coal, E3G Briefing Paper, January.

Pytlik, J. (2016). Prioritou by mělo být zachování pracovních míst v OKD. https://www. osphgn.cz/clanky/aktuality/j.-pytlik--prioritou-by-melo-byt-zachovani-pracovnichmist-v-okd.html (Accessed 21 December 2020).

Rečková, D., Rečka, L., \& Ščasný, M. (2017). Coal transition in the Czech Republic, IDDRI and Climate Strategies. 
Sábel, J. (2017). Byl to rok četných problémů, ale i historických úspěchů odborového svazu, říká předseda Jan Sábel. https://www.osphgn.cz/clanky/aktuality/2017--bylto-rok-cetnych-problemu--ale-i-historickych-uspechu-odboroveho-svazu--rikapredseda-jan-sabel.html (Accessed 15 April 2020).

Sábel, J. (2019a). Uhlíkové hysterii je nutné se postavit, dokud je čas, varuje předseda OS PHGN Jan Sábel. https://www.osphgn.cz/clanky/aktuality/uhlikove-hysterii-jenutne-se-postavit--dokud-je-cas--varuje-predseda-os-phgn-jan-sabel.html (Accessed 15 April 2020).

Sábel, J. (2019b). V Evropské unii rozhodují o uhlí a energetice „zelené“ mozky, ř́íá předseda OS PHGN Jan Sábel. https://www.osphgn.cz/clanky/aktuality/v-evropskeunii-rozhoduji-o-uhli-a-energetice----zelene----mozky--rika-predseda-os-phgnjan-sabel.html (Accessed 15 April 2020).

Społeczny Pre_COP24. (2018). Polska Droga do czystego środowiska, Katowice, 08-12 August 2018.

Stanovisko Sdružení. (2017). Stanovisko Sdružení hornických odborů. https://www. osphgn.cz/clanky/aktuality/stanovisko-sdruzeni-hornickych-odboru.html (Accessed 15 April 2020).

The Office of the Government of the Czech Republic. (2015). National Reform Programme of the Czech Republic.

Thomas, C. J. (ed.) (2004). Research guide to U.S. and international interest groups. WestportLondon: Praeger.

Trappmann, V. (2012). Trade unions in Poland. Current situation, organisation and challenges. Friedrich Ebert Stiftung Study, March.

Vandaele, K. (2019). Bleak prospects: Mapping trade union membership in Europe since 2000. Brussels: European Trade Union Institute.

Veverkova, S., Wegenschimmel, P. (2016). 2015 Annual review of labour relations and social dialogue. Czech Republic, Bratislava, March.

Von der Leyen, U. (2019). A Union that strives for more. My agenda for Europe. Political guidelines for the next European Commission 2019-2024. https://ec.europa.eu/commission/ sites/beta-political/files/political-guidelines-next-commission_en.pdf (Accessed 29 December 2020).

World Energy Council. (2000). Restructuring and privatizing the coal industries in Central and Eastern Europe and the CIS. London.

Zientara, P. (2009). Restructuring the coal mining industry: Unionism, conflict, and cooperation: evidence from Poland. Eastern European Economics, 47(1), 41-59. doi: 10.2753/eee0012-8775470103

Związki zawodowe. (2014a). Związki Zawodowe Górnictwa Węgla Kamiennego, Katowice, 29 April 2014.

Związki zawodowe. (2014b). Związki Zawodowe Górnictwa Węgla Kamiennego, Warszawa, 01 October 2014.

Związki zawodowe. (2018a). PZZ "Kadra”, ZZG w Polsce, NSZZ "Solidarność": Stanowisko Górniczych Central Związkowych skupionych w Radzie Koordynacyjnej industriAll Polska, Katowice, 22 February 2018.

Związki zawodowe. (2018b). Szkic stanowiska Forum ZZ, NSZZ „Solidarnos'c” oraz OPZZ ws. polityki klimatyczno-energetycznej, które będzie przedstawione na COP24 w Katowicach.

ZZGP. (2015). Zakładowa Organizacja Koordynacyjna Związku Zawodowego Górników w Polsce Kompanii Węglowej S.A.: Stanowisko Związku Zawodowego Górników w Polsce do Projektu Polityki energetycznej Polski do 2050 roku, Katowice, 11 September 2015. 